\title{
STT REAL BATAM PEDULI: \\ Mendukung Program Pemerintah Melalui Pemberian Masker di Rumah Sakit Demi Memutuskan Mata Rantai Penyebaran Covid-19
}

\author{
Fransiskus Irwan Widjaja1, Ronald Sianipar², Benteng M. M Purba ${ }^{3}$, Ardy Lahagu', \\ Talizaro Tafonao ${ }^{5}$, Johannis Siahaya ${ }^{6}$, Munatar Kause ${ }^{7}$ \\ $1,2,3,4,5$ Sekolah Tinggi Real Batam \\ ${ }^{6,7}$ Prodi Teologi, STAK Teruna Bhakti \\ *irwanwidjaja.fiw@gmail.com
}

\begin{abstract}
Since it was officially announced by the government, that covid has entered Indonesia and the government is working hard to deal with the transmission. Galang Island Infection Special Hospital was built quickly. As a lay community and educational institution in Batam city, STT Real through LPMM in general and PKM Real in particular took part. Especially with the absence of medical masks. PKM STT Real Batam.The purpose of providing these masks is to help the government, especially the RSKI, to have sufficient stock of masks so that medical staff / health workers work without psychological burdens will run out of masks. The methods used are fundraising, searching/purchasing masks and giving directly to $N$-users in this case are medical personnel and RSKI staff volunteers. This gift has had a very positive impact on STT Real Batam for its concern and greatly helped RSKI in overcoming the shortage of pioneering masks and spearheading services.

Keywords: Real Academic Community, Caring, Masks, RSKI Medical, Galang
\end{abstract}

Abstrak
ejak di umumkan oleh pemerintah secara resmi, bahwa covid telah masuk ke Indonesia dan pemerintah bekerja keras untuk menangani penularan. Rumah Sakit Khusus Infeksi pulau Galang di bangun dengan cepat. Sebagai masyarkat awam dan Lembaga Pendidikan yang ada di kota Batam, STT Real melalui LPMM secara umum dan secara khusus PKM Real turut ambil bagian. Terlebih lagi dengan adanya kekosongan masker medis. PKM STT Real Batam Tujuan dari pemeberiaan masker ini adalah untuk membantu pemerintah khususnya RSKI supaya memiliki stok masker yang cukup sehingga tenaga medis/ nakes bekerja tanpa beban psikis akan kehabisan masker. Metode yang digunakan adalah penggalangan dana, pencarian/pembelian masker dan pemberian secara langsung kepada $\mathrm{N}$-user dalam hal ini adalah tenaga medis dan realawan para petugas RSKI. Pemberian ini ini sangat berdampak positif kepada STT Real Batam akan kepedulian dan sangat menolong RSKI dalam mengatasi kekurangan masker perintis dan ujung tombak pelayanan.

Kata kunci: Civitas Akademik Real, Peduli, Masker, Medis RSKI, Galang

\section{PENDAHULUAN}

Dunia sedang berduka di kejutkan dengan mengalami masa yang berat sejak awal tahun 2020 ini dengan adanya fenomena Corona Virus Disease COVID-19. ${ }^{1}$ Penyakit Coronavirus 2019 (COVID19) adalah virus yang cepat menular begitu cepat. Pada tanggal 2 Maret 2020, Indonesia untuk pertama kalinya mengonfirmasi kasus COVID-19 dan telah menyebar di 34 provinsi di Indonesia (Gugus Tugas Percepatan Penanganan COVID-19, 2020). ${ }^{2}$ COVID-19 telah menjadi musuh bersama ketika berhadapan dengan keselamatan (jiwa). Keselamatan hidup umat di atas segala-galanya dengan banyaknya yang terpapar berdampak pada kurangnya angka ketersediaan tempat tidur di rumah sakit, baik itu di Jakarta maupun di berbagai daerah lainnya.

1 Santoso Tri Raharjo Alma Fildzah Aufar, 'Kegiatan Relaksasi Sebagai Coping Stress Di Masa Pandemi Covid-19', Jurnal Kolaborasi Resolusi Konflik, 2.2 (2020):157-163, DOI: 10.24198/jkrk.v2i2.29126.

2 Ikfina Chairani, "Dampak Pandemi Covid-19 Dalam Perspektif Gender Di Indonesia," Jurnal Kependudukan Indonesia Edisi Khusus Demografi Dan Covid-19 7, no. 6 (2020): 555-564. 
Mengantisipasi kasus yang terus meningkat, pemerintah melalui Kementerian Pekerjaan Umum dan Perumahan Rakyat (PUPR) membangun sebuah rumah sakit di eks kamp pengungsi Vietnam di Pulau Galang. ${ }^{3}$ Pengumuman mengenai pembangunan rumah sakit ini pertama kali disampaikan kepada masyarakat pada 3 Maret 2020. Sejak itu, RSKI Pulau Galang digadang-gadang sebagai rumah sakit darurat seperti yang ada di Wuhan, Tiongkok. RSKI Pulau Galang mulai dibangun pada 8 Maret 2020 dimulai dengan melakukan proses pembersihan lahan terlebih dahulu. Selanjutnya. pembangunan rumah sakit ini juga menggunakan metode pembangunan rumah sakit darurat yang dibangun di Kota Wuhan, Tiongkok. Material dan perakitan peralatan medis dilakukan di Jakarta yang nantinya proses instalasi dilakukan di Rumah Sakit Pulau Galang. Ini dilakukan agar pembangunan dan kesiapan rumah sakit untuk penanganan virus korona ini lebih cepat ${ }^{4}$

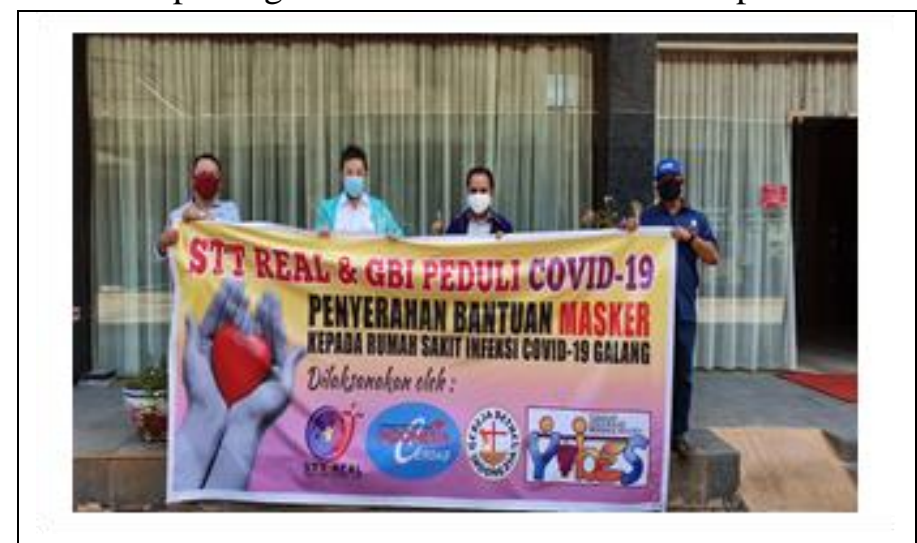

Gambar 1. Foto Tim atau dosen dari STT Real Batam

Semula pembangunan RSKI ditargetkan selesai selama 2-3 minggu atau pada akhir Maret $2020^{5}$, namun RSKI akhirnya baru bisa resmi beroperasi pada 6 April 2020. ${ }^{6}$ Berdiri nya RSKI juga menggerakkan masyarakat Batam berbondong bondong untuk untuk ambil bagian dan tidak terlepas STT Real ${ }^{7}$. Pada awal bulan Mei 2020 LPPM Real mengadakan rapat dan mengumpulkan partner Kerjasama gereja, khususnya GBI yang ada di Kepulauan Riau (BPD GBI Kepri), Indonesia Cerdas, yaitu lembaga partner pelayanan dan pemakai alumni serta Yayasan Yabes untuk mengumpulkan donasi. Donasi akan di belanjakan untuk pembelian Masker medis yang dalam keadaan kosong di seantero Indonesia ${ }^{8}$. Pembelian dan pencarian masker akan di lakukan partner di Jakarta dan dalam hal ini melibatkan pihak Yayasan Transformasi Indonesia cerdas. Singkat cerita, akhirnya PKM Real dapat menyumbangkan 3000 pieces masker medis yang menjadi komoditi Langkah saat itu. Pada tanggal 05 Mei 2020, Bantuan masker di donasikan langsung ke RSKI, dalam hal ini di terima langsung oleh bagian logistik laboratorium analisi specimen.

${ }^{3}$ Yudha M Putra, "Sejarah Rumah Sakit Bekas Kamp Vietnam Di Pulau Galang".," Republika (Jakarta, March 2020).

${ }^{4}$ Yuniati Jannatun Naim, "Pemerintah Mulai Bangun RS Khusus Di Pulau Galang,” Antaranews (Batam, March 2020).

${ }^{5}$ Muhammad Choirul, “"RS Corona’ Dibangun Di Pulau Galang, Target Kelar 2 Minggu," CNBC Indonesia (Jakarta, March 2020).

${ }^{6}$ Abdul Basith, "Jokowi Pastikan Pekan Depan Rumah Sakit Darurat Covid-19 Di Pulau Galang Beroperasi," Kontan.Co.Id (Batam, April 2020).

7 Zabur Anjasfianto, "Galang Dana Terkumpul Rp 31 Juta, Salurkan Donasi Untuk Tenaga Medis Bantu Penanganan Covid-19 Artikel Ini Telah Tayang Di TribunBatam.Id Dengan Judul Galang Dana Terkumpul Rp 31 Juta, Salurkan Donasi Untuk Tenaga Medis Bantu Penanganan Covid-19, Https://," Tribun Batam. Merdeka.Com.

${ }^{8}$ Muhammad Radityo, “Kelangkaan Masker Imbas Panic Buying Di Tengah Masyarakat,” 
Berasarkan latar belakang di atas, maka tujuan kegiatan pengabdian ini adalah mengedukasi masyarakat khususnya civitas akdemik STT Real Batam bahwa kepedulian ditengah krisis ini sangat penting dilakukan.

\section{METODE}

Metode pendekatan yang dilakukan dalam kegiatan ini adalah metode secara humanis serta berdasarkan kebutuhan di lapangan. Kebutuhan masker sangat dibutuhkan oleh Rumah Sakit Khusus Infeksi (RSKI) Pulau Galang Batam, sehingga tim STT Real menghimbau dan memberi pengumuman di media social WA dan pendekatan secara peribadi kepada mitra/partner kerja STT Real Batam mengenai kebutuhan tersebut yang telah di bangun tetapi perlu di topang dengan kebutuhan yang mendasar dari masyarakat. PKM Real Batam ingin sekali terlibat dan memberi kontribusi. Hal ini di respon dengan baik oleh mitra dan rekan kerja untuk mendukung program tersebut.

\section{HASIL DAN PEMBAHASAN}

1. Penanda tangan penyerahan bantuan masker kepada pihak Rumah Sakit Khusus Infeksi (RSKI) Pulau Galang Batam

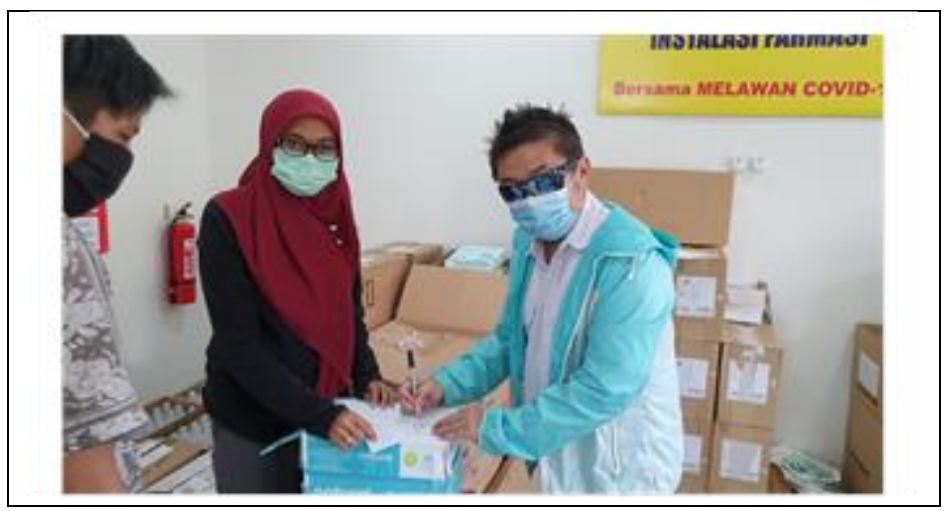

\section{Gambar 2. Foto Penanda tangan penyerahan bantuan masker antara pihak rumah sakit dengan pimpinan STT Real Batam}

Sebelum dilakukan penyerahan bantuan maka yang pertama dilakukan adalah Penanda tangan. Penanda tangan ini salah satu bukti bahwa bantuan masker telah diserahkan kepada pihak rumah sakit dan telah di terima oleh pihak rumah sakit. Selain itu, penanda tangan ini juga sebagai bukti pertanggung jawaban kepada pihak-pihak yang telah berkontribusi dalam pengadaan masker tersebut. penyerahan bantuan masker.

2. Penyerahan bantuan masker

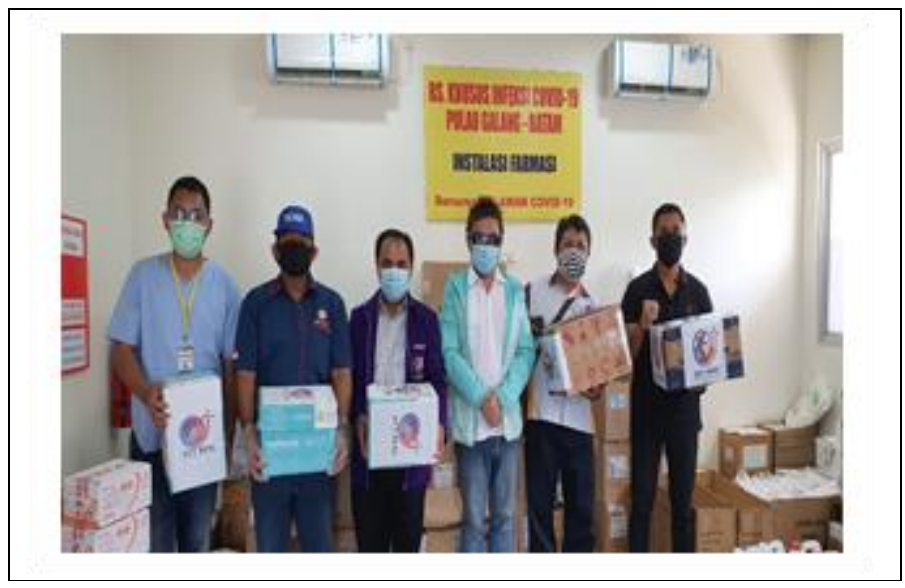

Gambar 3. Foto pada saat menyerahkan bantuan masker kepada pihak rumah sakit 
Penyerahan bantuan masker ini terima langsung oleh yang mewakili dari pihak rumah sakit. Pihak rumah masker ini untuk digunakan dalam kebutuhan penangan Covid-19. Pada waktu adanya Covid-19 ini ada beberapa rumah sakit yang kekurang masker termasuk Rumah Sakit Khusus Infeksi (RSKI) Pulau Galang Batam.

3. Penyerahan Piagam penghargaan dari rumah sakit kepada Sekolah Tinggi Teologi Real Batam

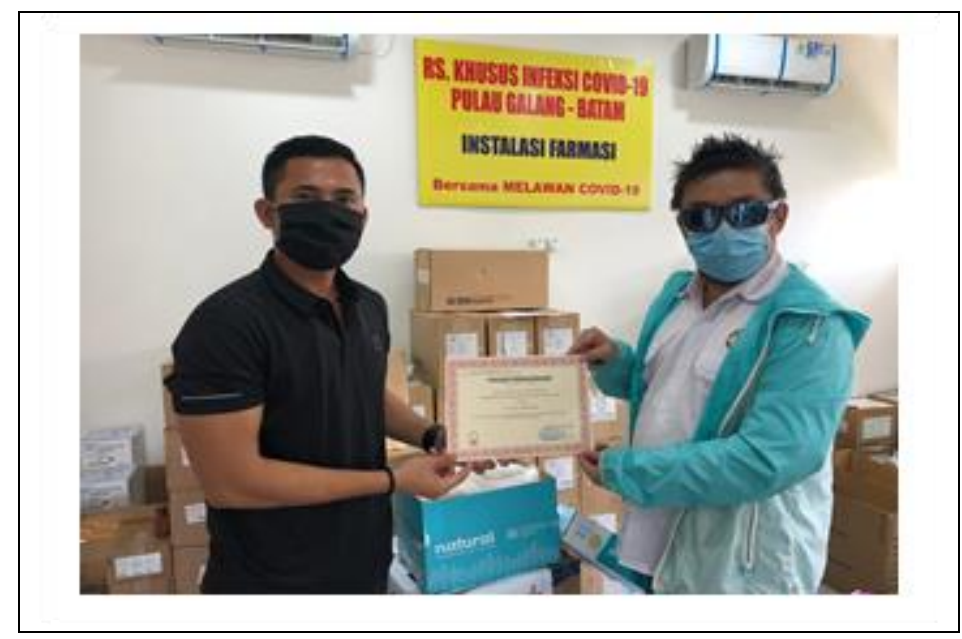

\section{Gambar 3. Penyerahan Piagam kepada pimpinan STT Real Batam dari Rumah Sakit Khusus Infeksi (RSKI) Pulau Galang Batam}

Piagam penghargaan yang diberikan oleh rumah sakit adalah satu bentuk ucapan terimaksih kepada tim STT Real Batam atas kepedulian dalam mendukung pihak rumah sakit dalam menangani Covid-19.

\section{Pembahasan}

Di masa pandemi ini sangat penting untuk saling membantu (bergotoroyong) satu dengan yang lain. Kata-kata ini yang selalu serukan oleh pemerintah kepada masyarakat Indonesia. Pemerintah Indonesia mengajak masyarakat untuk saling peduli satu dengan yang lain dalam menghadapi Covid19 ini. Dalam penangan Covid-19 ini tidak hanya tugas pemerintah saja tetapi masyarakat Indonesia harus mengambil bagian untuk menekan terjadinya penyebaran Covid-19. Dalam kajian yang dilakukan oleh Mulyadi menegaskan bahwa kepedulian (partisipasi) masyarakat menjadi kunci utama untuk pencegahan penyebaran wabah Covid-19. ${ }^{9}$ Artinya kepedulian masyarakat terhadap satu dengan yang lain menjadi kunci utama melalui aktifitas yang dilakukan dan yang dapat dirasakan oleh semua orang. Kegiatan kepedulian sosial ini tidak hanya dilakukan di masyarakat sekitar tetapi dilakukan kepada selurus elemen yang memerlukan bantuan. Kementerian Koordinator Bidang Pembangunan Manusia dan Kebudayaan (Kemenko PMK) dalam hal ini Bapak Muhadjir Effendy mengajak masyarakat untuk rasa kepedulian dalam menghadapi pandemi Covid-19, sehingga budaya gotong royong pun benar - benar diterapkan. Di tengah tantangan menghadapi pandemi global Covid-19, kepekaan hati dan solidaritas masyarakat Indonesia terus diuji. ${ }^{10}$ Dalam aktifitas yang dilakukan oleh Widjaja, dkk mengatakan bahwa kepedulian adalah salah satu bukti kerja nyata dalam kehidupan

\footnotetext{
${ }^{9}$ Mohammad Mulyadi, "Partisipasi Masyarakat Dalam Penanganan Penyebaran Covid-19," Pusat Penelitian Badan Keahlian DPR RI XII, no. 8 (2020): 13-18.

${ }^{10}$ Dwi Prasetya, "Teladan Gotong-Royong Masyarakat Di Tengah Pandemi," Kemenko PMK.
} 
bersosial. ${ }^{11}$ Hal yang ditegaskan oleh Probosiwi, dkk mengatakan bahwa meningkatkan nilai solidaritas sosial di masa sulit seperti ini maka melahirkan suatu hubungan manusia timbal balik. ${ }^{12}$

Inilah yang dilakukan oleh tim dosen Sekolah Tinggi Teologi Real Batam selama masa pandemi, dimana kampus ini mewujudkan rasa kepedulian melalui pembagian masker di Rumah Sakit Khusus Infeksi (RSKI) Pulau Galang Batam. Rumah Sakit Khusus Infeksi (RSKI) Pulau Galang Batam sangat membutuhkan dukungan dari segi kebutuhan medis saat itu, karena rumah sakit ini menjadi salah satu rujukan dalam penangan Covid-19. Dengan melihat kebutuhan tersebut civitas akademik STT Real turut mendukung dan menyumbangkan masker untuk mendukung kinerja para medis dalam menangani orang yang terkena Covid-19. Menurut Munthe, dkk bahwa kebutuhan masker sangat mendesak saat ini sabagai alat pelindung dalam menghadapi ganasnya Covid-19, karena dengan menggunakan masker dapat mengurangi terserang penyakit Corona Virus. ${ }^{13}$

Selama ini yang sering kita tahu adalah tenaga medis yang menolong masyarakat tetapi sekarang ini medis mengharapkan bantuan dari masyarakat dalam memutuskan mata rantai atau mendukung dari segi lain dalam pengadaan fasilitas berkaitan dengan kebutuhan rumah sakit di masa pandemi. Salah satu harapan tenaga medis kepada masyarakat adalah taat dalam mengikuti protokol kesehatan, karena sampai saat ini sebagian besar masyarakat kurang peduli terhadap pentingnya alat pelindung diri dan mencuci tangan dengan prosedur yang telah ditetapkan. ${ }^{14}$

Kepedulian itu tidak hanya dilakukan dengan menyumbangkan barang kepada tenaga medis seperti yang telah dilakukan di atas, tetapi kepedulian itu juga diperlihat melaui ketaatan khususnya aturan-aturan yang berlaku di masa pandemi. Ini juga salah satu cara kita menolong dan peduli kepada para tenaga medis yang ada di rumah sakit. Tenaga medis sekarang menjadi pahlawan kesehatan dalam membantu masyarakat yang menjadi korban Covid-19, untuk mengurangi beban medis, kita masyarakat harus taat protokol kesehatan agar tenaga medis mengurangi beba dalam menangi Covid19 yang semakin mewabah ini.

Pembagian masker ini kepada Rumah Sakit Khusus Infeksi (RSKI) Pulau Galang Batam sangat bermanfaat. Selain itu mereka sangat berterimakasih atas kepedulian masyarakat khusunya parat tim STT Real Batam. Hal-hal seperti ini yang diharapkan oleh pemerintah bahwa dalam penangan Covid19 masyarakat mengambil bagian dan turut memutuskan mata rantai penyebaran Covid-19.

\section{SIMPULAN}

Aktifitas ini dilakukan oleh PKM STT Real Batam dengan mitra adalah wujud dari pengabdian dosen di masyarakat. Hasil kegiatan dari pengabdian masyarakat ini memberikan dampak positif kepada tenaga medis yang bekerja di RSKI. Kelangkaan masker bisa di atasi dan memiliki stok yang cukup. Sekalipun hasil pemberian ini masih belum maksimal seperti yang diharapkan tetapi untuk tekad dan maksud baik sangat di hargai. Hal yang penting dalam kegiatan ini adalah para mitra bisa melihat dan terlibat langsung.

Sumber Dana dari kegiatan ini adalah di lakukan oleh alumni dan para sahabat sahabat yang peduli Batam dan PKM Real hanya mengfasilitasi dan mengantarkan donasi tersebut.

${ }^{11}$ Fransiskus Irwan Widjaja et al., "Pelayanan Dan Bakti Sosial Pasca Banjir Di Kota Tanjungpinang: Sebagai Wujud Rasa Kemanusiaan,” Jurnal Abdimas Ilmiah Citra Bakti 2, no. 1 (2021): 61-71.

${ }^{12}$ Ratih Probosiwi and Afrinia Lisditya Putri, "Jogo Tonggo : Solidaritas Masyarakat Di Era Pandemi Covid-19," SOSIO KONSEPSIA: Jurnal Penelitian dan Pengembangan Kesejahteraan Sosia Vol 10, no. 02 (2021): 177-192.

${ }^{13}$ Seri Asnawati et al., "Penyuluhan Dan Sosialisasi Masker Di Desa Sifahandro Kecamatan Sawo Sebagai Bentuk Kepedulian Terhadap Masyarakat Ditengah Mewabahnya Virus Covid 19," Jurnal Abdimas Mutiara 1, no. September (2020): 115-123.

${ }^{14}$ Saat Pandemi, Covid- D I Papanggo, and R T Rw, "Tingkat Kepedulian Masyarakat Terhadap Penggunaan APD Saat Pandemi Covid-19 Di Papanggo RT13/RW05,” Junal JAKHKJ 7, no. 1 (2021): 33-38. 


\section{Ucapan Terima Kasih}

Dengan terlasksanaanya kegiatan ini, kami mengucapkan banyak terimaksih kepada Sinode Gereja Bethel Indonesia dalam hal ini BPD GBI Kepulauan Riau, Yayasan Transfomasi Indonesia Cerdas dan juga Yayasan Yabez yang boleh ikut ambil bagian di bidang masing masing dalam hal memberi. Semoga pelaksanaan kegiatan ini dapat bermanfaat dan memberikan kontribusi yang baik dalam perlindungan buat tenaga medis yang sedang bekerja dan melayani masyarakat. Kami juga menyampaikan penghargaan yang setingginya-tingginya kepada Lembaga Pengabdian Masyarakat (LPM)Sekolah Tinggi Teologi REAL Batam yang telah ambil bagian dalam kegiatan ini memberikan kesempatan dan dukungan baik secara materi maupun non-materiil dalam pelaksanaan kegiatan pengabdian kepada masyarakat.

\section{DAFTAR PUSTAKA}

Alma Fildzah Aufar, Santoso Tri Raharjo. "Kegiatan Relaksasi Sebagai Coping Stress Di Masa Pandemi Covid-19,.” Jurnal Kolaborasi Resolusi Konfli 2, no. 2 (2020): 157.

Anjasfianto, Zabur. "Galang Dana Terkumpul Rp 31 Juta, Salurkan Donasi Untuk Tenaga Medis Bantu Penanganan Covid-19 Artikel Ini Telah Tayang Di TribunBatam.Id Dengan Judul Galang Dana Terkumpul Rp 31 Juta, Salurkan Donasi Untuk Tenaga Medis Bantu Penanganan Covid19, Https://." Tribun Batam.

Asnawati, Seri, Jasmen Manurung, Lia Rosa, and Veronika Sinaga. "Penyuluhan Dan Sosialisasi

Masker Di Desa Sifahandro Kecamatan Sawo Sebagai Bentuk Kepedulian Terhadap Masyarakat Ditengah Mewabahnya Virus Covid 19.” Jurnal Abdimas Mutiara 1, no. September (2020): 115123.

Basith, Abdul. "Jokowi Pastikan Pekan Depan Rumah Sakit Darurat Covid-19 Di Pulau Galang Beroperasi.” Kontan.Co.Id. Batam, April 2020.

Chairani, Ikfina. "Dampak Pandemi Covid-19 Dalam Perspektif Gender Di Indonesia.” Jurnal Kependudukan Indonesia Edisi Khusus Demografi Dan Covid-19 7, no. 6 (2020): 555-564.

Choirul, Muhammad. "'RS Corona' Dibangun Di Pulau Galang, Target Kelar 2 Minggu." CNBC Indonesia. Jakarta, March 2020.

Mulyadi, Mohammad. "Partisipasi Masyarakat Dalam Penanganan Penyebaran Covid-19." Pusat Penelitian Badan Keahlian DPR RI XII, no. 8 (2020): 13-18.

Naim, Yuniati Jannatun. "Pemerintah Mulai Bangun RS Khusus Di Pulau Galang.” Antaranews. Batam, March 2020.

Pandemi, Saat, Covid- D I Papanggo, and R T Rw. "Tingkat Kepedulian Masyarakat Terhadap Penggunaan APD Saat Pandemi Covid-19 Di Papanggo RT13/RW05.” Junal JAKHKJ 7, no. 1 (2021): 33-38.

Prasetya, Dwi. "Teladan Gotong-Royong Masyarakat Di Tengah Pandemi." Kemenko PMK.

Probosiwi, Ratih, and Afrinia Lisditya Putri. "Jogo Tonggo : Solidaritas Masyarakat Di Era Pandemi Covid-19." SOSIO KONSEPSIA: Jurnal Penelitian dan Pengembangan Kesejahteraan Sosia Vol 10, no. 02 (2021): 177-192.

Putra, Yudha M. “Sejarah Rumah Sakit Bekas Kamp Vietnam Di Pulau Galang".” Republika. Jakarta, March 2020.

Radityo, Muhammad. "Kelangkaan Masker Imbas Panic Buying Di Tengah Masyarakat." Merdeka.Com.

Widjaja, Fransiskus Irwan, Talizaro Tafonao, Benteng Martua Mahuraja Purba, Sabar Manahan Hutagalung, Candra Gunawan Marisi, Fredy Simanjuntak, Selvyen Sophia, and Efvi Noyita. 
"Pelayanan Dan Bakti Sosial Pasca Banjir Di Kota Tanjungpinang: Sebagai Wujud Rasa Kemanusiaan.” Jurnal Abdimas Ilmiah Citra Bakti 2, no. 1 (2021): 61-71. 